\title{
Growth curve of locally adapted Pantaneiro cows raised under natural conditions
}

\author{
Eleonora Araújo Barbosa ${ }^{1}$, Andréa Alves do Egito², Urbano Gomes Pinto de Abreu ${ }^{3}$, \\ Raquel Soares Juliano ${ }^{3}$, Joseane Padilha da Silva ${ }^{4}$, Arthur da Silva Mariante ${ }^{4}$, Alexandre \\ Floriani Ramos ${ }^{4}$
}

\footnotetext{
${ }^{1}$ Faculdade de Agronomia e Medicina Veterinária, Universidade de Brasília, Brasília, DF, Brasil.

${ }^{2}$ Embrapa Gado de Corte, Campo Grande, MS, Brasil.

${ }^{3}$ Embrapa Pantanal, Corumbá, MS, Brasil.

${ }^{4}$ Embrapa Recursos Genéticos e Biotecnologia, Brasília, DF, Brasil.
}

\begin{abstract}
The objective of this study was to use morphometric and ultrasound evaluations to estimate the growth curve of the Pantaneiro cattle breed, raised in its natural habitat, aiming at the re-insertion of this breed in production systems. One hundred and three females, aging from months to 11 years, and raised on native pastures, were evaluated. The animals belonged to the Conservation Nucleus of Embrapa Pantanal, located in the Pantanal of Mato Grosso do Sul (Brazil). Weight, thoracic perimeter (TP), body length (BL), rump height (RH), height at withers (HW), hip height (HH), depth (DP), distance between the ilia (DI) (cm) and rib-eye area (REA) were measured. To relate the measurements with the age of the animals, the univariate regression model was used, assigning the variable response to gamma distribution. The Pearson correlation between variables was also estimated. The inflection point of the growth curve was 37 months for HH; between 38 and 39 months for TP and HW; between 40 and 41 months for DI, HH and DP; and 45 months for BL. The REA results could not fit in a statistical model. The majority of the variables presented a correlation above $60 \%$ among themselves, except for REA $\times$ Age, of $15.81 \%$; $\mathrm{REA} \times \mathrm{HW}$, of $34.44 \%$; $\mathrm{HH} \times \mathrm{Age}$, of 46.19 ; $\mathrm{HH} \times \mathrm{DI}$, of $58.07 \%$; REA $\times \mathrm{HH}$, of $24.57 \%$; and REA $\times \mathrm{TP}$, of $39.9 \%$. The cows showed maturity age at 40 months, which may have occurred because they were raised in natural farming conditions. In Pantaneiro cows reared in extensive systems only on natural pastures, the use of ultrasound is not effective to estimate the curve of muscular development, perhaps because this breed was not selected for weight gain.
\end{abstract}

Key Words: animal production, biometric, cattle, conservation, genetic resources, ultrasound

\section{Introduction}

Even though the rich ecosystem of the Brazilian Pantanal region can be considered harsh for some cattle breeds, the Pantaneiro cattle has been naturally selected in that region and is perfectly adapted to that ecosystem with its native pastures, which sometimes do not meet the requirements of other cattle breeds. Thus, the Pantaneiro cattle is an excellent option for sustainable production in the Pantanal region due to its unique traits, acquired after almost 500 years of natural selection, which even include the habit of grazing in flooded areas (Mariante et al., 2009).

Carcass biometric measurements assist indirectly and economically the evaluation of performance, and are essential for the assessment of growth and development of the animals. It is known that these characteristics are inherent to breed, sex and food type (Macitelli et al., 2005). Just one measurement cannot define the carcass characteristics, but combinations of these measurements can be used to establish indexes that enable the adjustment of the data obtained, to better compare carcass and animal performance.

Breed selection has allowed an increase in meat production, but presently there are concerns about meat quality (Alberti et al., 2008). According to Koury Filho (2005), it is possible that animals with different growth curves present different capacity to utilize energy resources available for production. So, different genotypes would be recommended for different environments, not simply by body mass, but also by morphological type. It is extremely important to study not only the muscle development of locally adapted breeds, but the quality of their meat as well.

The importance of establishing the growth curve of animals becomes clear if we analyze the beef production chain, where animals are required to produce better and in natural conditions. The evaluation of the development curve in cattle can be used in the establishment of breeding programs and also in feeding systems for a better feed 
conversion efficiency and therefore greater animal productivity.

The objective of this study was to evaluate the growth curve of Pantaneiro cattle and to estimate the age at body maturity of these animals, through morphometric measurements and with the aid of ultrasound.

\section{Material and Methods}

One hundred and three Pantaneiro cows were evaluated. The animals had been raised in extensive native grazing, ranging from 7 months to 11 years old, and belonged to Conservation Nucleus of the Nhumirin Farm (Embrapa Pantanal), located in the Pantanal of Mato Grosso do Sul (MS, Brazil).

The annual precipitation in the region is $1,200 \mathrm{~mm}$ and the annual average temperature is $25.5^{\circ} \mathrm{C}$, varying from 20.8 to $28.0{ }^{\circ} \mathrm{C}$. The monthly maximum average temperatures range from 28.3 to $34.0{ }^{\circ} \mathrm{C}$, but during the period from September to January, the daily absolute maximum may exceed $40.0{ }^{\circ} \mathrm{C}$. The annual relative humidity is $82 \%$, ranging between 75 and $86 \%$ (Mazza et al., 1994). The distribution system of the vegetation is mosaic units, alternating cerradões and seasonal forest in the ridges, wet field and seasonal wetlands, on the flooded and surrounding ponds, savannas and fields in intermediate parts of the relief. In the lower portion of the relief, there is great diversity of forage species. The vegetation units used as native pasture are diverse in their floral compositions, and also in their structure (clean fields, dirty fields, savanna fields) and ecologies (Santos et al., 2009).

The animals were weighed at the beginning of the experiment, with the aid of an analog scale and measured biometrically: thoracic perimeter $(\mathrm{cm})$, body length $(\mathrm{cm})$, and rump height $(\mathrm{cm})$ using a tape measure; height at withers $(\mathrm{cm})$, hip height $(\mathrm{cm})$, depth $(\mathrm{cm})$ and distance between the ilia $(\mathrm{cm})$, with the aid of a hipometer. For these measurements, the following criteria were considered:

Height at withers: distance from the ground to the highest point of the withers; Hip height: distance from the ground to the highest point of the rump; Thoracic perimeter: measure of the chest of the animal taken from the caudal part of the scapula, the sternum and the spinal processes of the thoracic vertebrae; Body length: measured from the tip of the palette into the ischial tuberosity; Rump height: distance between the coxal tuberosity of the ilium to the ischial tuberosity; Depth: measure of the chest, performed with a hipometer; Distance between ilia: distance between the two coxal tuberosities.
With the aid of a real-time ultrasound device (Pie Medical Aquila model, $18 \mathrm{~cm}$ linear transducer with a frequency of $3.5 \mathrm{MHz}$ ), using an acoustic coupler (standoff) and vegetable oil, images of the longissimus dorsi, between the 12th and the13th ribs, were collected to measure rib-eye area (REA) $\left(\mathrm{cm}^{2}\right)$. The images were evaluated using the EView (EView - Echo Image Viewer, Pie Medical Equipment BV) computer software.

To relate the measurements with the age of the animals, the univariate regression model was used, assigning to the response variable gamma distribution, since all the variables studied showed asymmetry around the mean.

First, the relationship between each biometric variable and age of animals was modeled according to the growth curves described in the literature, such as Logistic function, Gompertz, modified Gompertz and Pearl Curve. However, the coefficients of explanation of these models were poor $\left(\mathrm{R}^{2}<60 \%\right)$. In addition, the residual graphs versus the values predicted by the fitted curves presented problems, suggesting poor fit of these curves. Thus, a search was performed to find the distribution that would best accomodate the variability present in the data using Generalized Linear Models (GLM) (McCullagh \& Nelder, 1989). As its name suggests, the GLM generalize the classical regression model as follows.

The response variable must be derived from the exponential family, in other words, it should be written in the following form:

$$
f(Y, \theta, \phi)=\exp \left[\frac{1}{a(\phi)}[Y \theta-b(\theta)]+c(Y, \phi)\right],
$$

with the expected value and variance for the random variable $\mathrm{Y}$ given respectively by: $E[Y]=\mu=b^{\prime}(\theta)$ and $V[Y]=a(\phi) b^{\prime \prime}(\theta)=a(\phi) V[\mu]$,

in which $\phi$ is the dispersion parameter data and $V[\mu]$ is known as a variance function and serves to characterize the distribution of the data. In this case, the linear predictor of classical models, $X \theta$, is now expressed by $\eta$; the relationship between the variable response and the linear predictor is made through a monotone and differentiable $g$ function, named link function, $g(\mu)=\eta$. In other words, to use a generalized linear model it is necessary to select the distribution of response variable and the appropriate link function to the data so that a large part of the variation is explained by the chosen model. For biometric variables, the distribution that best accommodated the variability was the Gamma distribution, due to its flexibility to capture additional variations. To detect the stabilization point on Gamma distribution set, the segmented regression model was applied. According to Robbins (1979), segmented regression model is type $\mathrm{y}=\mathrm{L}+\mathrm{U}^{*}(\mathrm{Z} 1)$, in which $\mathrm{L}$ represents the 
coordinate on the axis of the ordinate; and $\mathrm{U}$ is the slope coefficient of a line under the condition $\mathrm{Z} 1$ to $\mathrm{y} \neq 0$ with stabilization of the biometric measurements occurring at ages $\mathrm{R} \geq$ agesN, which corresponds to highest age studied: $\mathrm{Z} 1=($ ages $\mathrm{N}<\mathrm{R}) *(\mathrm{R}$-agesN $)$. Thus, the equation was defined by: $\mathrm{y}=\mathrm{L}+\mathrm{U}^{*}(\mathrm{R}-\mathrm{X})$. The probability level adopted for this test was $5 \%$. The analyses were developed in the program of statistical language $\mathrm{R}$, specifically in the segmented and GLM library.
The Pearson correlation between variables was estimated with the aid of the SAEG statistical program.

\section{Results}

The relationship between the biometric variables and the age of the animals, and the time when the growth of these animals is stabilized can be seen from the inflection point (Figure 1).
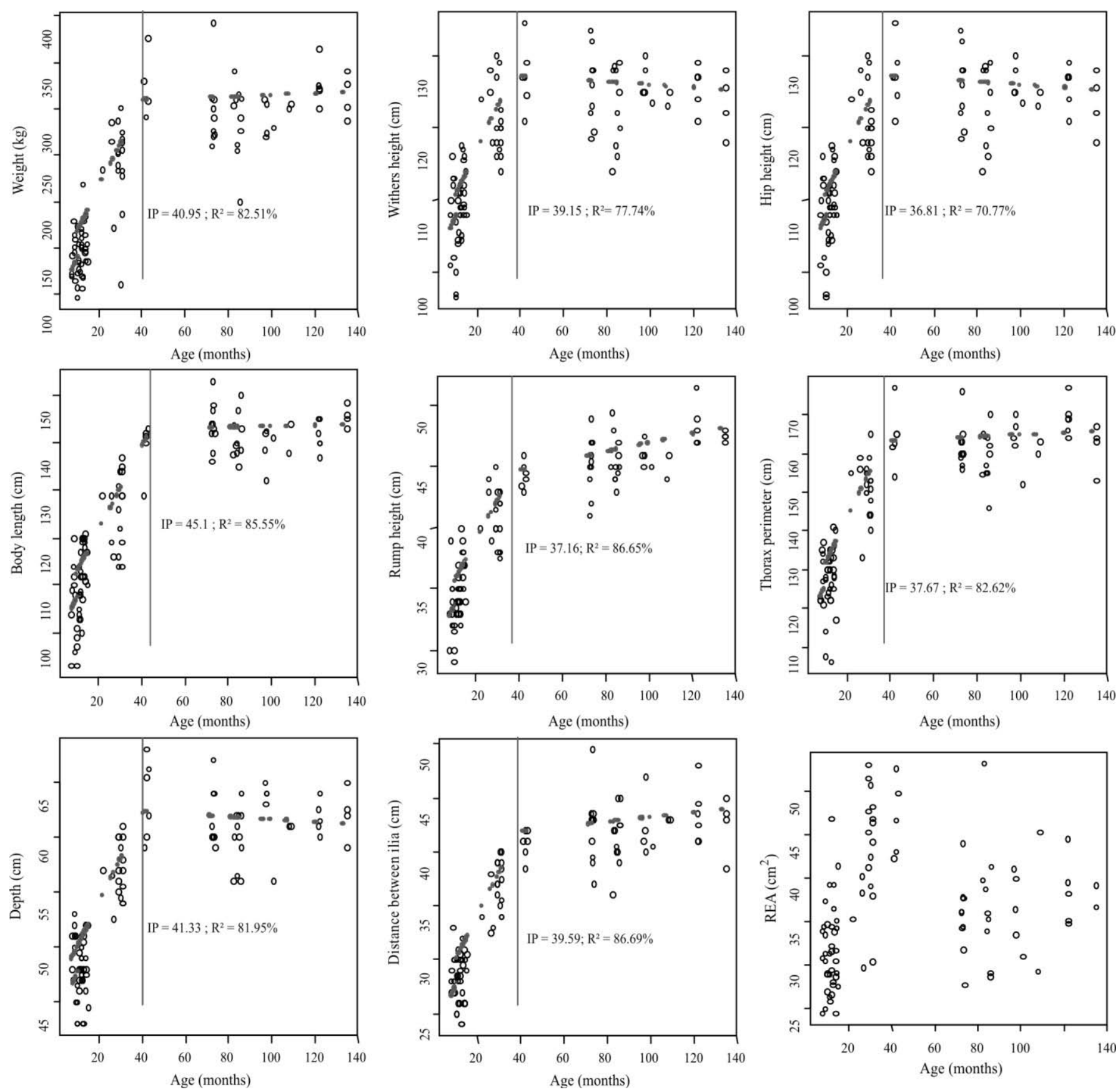

The vertical line indicates the inflection point (IP) of the development curve.

Figure 1 - Univariate relationship between biometric measurements (Y) and age of Pantaneiro cows (X), according to the segmented regression model assigning the Gamma distribution for the response variable (Y). 
Table 1 - Pearson correlations between morphometric and ultrasound measurements for Pantaneiro cows raised in an extensive system

\begin{tabular}{|c|c|c|c|c|c|c|c|c|c|}
\hline & Age & Weight & Height at withers & Hip height & Body length & Rump height & Thoracic perimeter & Depth & $\begin{array}{c}\text { Distance } \\
\text { between ilia }\end{array}$ \\
\hline Weight & $0.76^{*}$ & & & & & & & & \\
\hline Height at withers & $0.74 *$ & $0.92 *$ & & & & & & & \\
\hline Hip height & $0.46^{*}$ & $0.62 *$ & $0.67 *$ & & & & & & \\
\hline Body length & $0.77 *$ & $0.91^{*}$ & $0.90^{*}$ & $0.69^{*}$ & & & & & \\
\hline Rump height & $0.84 *$ & $0.91 *$ & $0.67 *$ & $0.63 *$ & $0.91 *$ & & & & \\
\hline Thoracic perimeter & $0.76^{*}$ & $0.95 *$ & $0.93 *$ & $0.64 *$ & $0.88 *$ & $0.92 *$ & & & \\
\hline Depth & $0.76^{*}$ & $0.94 *$ & $0.94 *$ & $0.66^{*}$ & $0.91 *$ & $0.90 *$ & $0.96^{*}$ & & \\
\hline Distance between ilia & $0.82 *$ & $0.93 *$ & $0.89 *$ & $0.58^{*}$ & $0.87 *$ & $0.89 *$ & $0.93^{*}$ & $0.92 *$ & \\
\hline Rib-eye area & 0.15 & $0.45^{*}$ & $0.34 *$ & 0.24 & $0.32 *$ & $0.28 *$ & $0.39 *$ & $0.37 *$ & $0.38^{*}$ \\
\hline
\end{tabular}

These results show the moment when the cows stabilize their development, starting to present a small and slow growth. It was noticed that first the growth rate of the hip of the animals decreased at around 37 months of age; then between 38 and 39 months of age, their growth rate of thoracic perimeter and height at the withers decreased; between 40 to 41 months, the growth rate of the distance between ilia, weight and depth decreased; and finally, at about 45 months of age, body length growth decreased.

Regarding the results of Pearon's correlations (Table 1), the majority of the morphometric variables presented a high positive correlation among themselves above $60 \%(\mathrm{P}<0.01)$. The correlations between REA and the morphometric measurements were between 34 and $58 \%(\mathrm{P}<0.01)$, except REA $\times$ Age $(15.81 \% ; \mathrm{P}<0.0565)$ and REA $\times$ HH $(24.57 \%$; $\mathrm{P}<0.06$ ).

\section{Discussion}

The initial growth phase is characterized by a rapid growth of the skeleton, muscle and other organs, with subsequent stabilization of visceral and skeletal development. However, muscular growth does not stop and the fat tissue start to grow. Finally, when skeletal and muscular growth reaches its limit or maturity, there is acceleration in fat accumulation (Pedroso et al., 2004). It could be seen in the Pantaneiro cows evaluated in this study that bone growth was quicker at approximately 38 months of age, represented by the height and length measures, while muscle growth took place at 41 months of age, represented by the increase in the following measurements: depth, width and circumference of the animal (Figure 1).

The fastest growth occurred between 15 and 20 months of age, for all morphometric measurements, which, according to Owens et al. (1993) may be related to the age when the animals reach puberty (between 13 and 17 months for Pantaneiro males) (Juliano et al., 2011). At that time, the animals reached the stage of accelerated growth, which is followed by the post puberty phase, between 20 and 40 months of age, when a continuous grow is evident, although with less intensity. At 40 months of age, the animals entered a stage of self-inhibition of growth, and presented characteristics of body maturity (Figure 1). According to Owens et al. (1993), at that age the animals are nearly at the end of their carcass conformation, when growth is minimal.

The inflection point, which indicates the time when the animal growth is stabilized, was estimated at approximately 40 months of age for all variables (Table 1). This was possibly because of the farming system used, in which the animals went through times of feed restriction due to environmental conditions, and to the low quality and quantity of pastures, which according to Prado et al. (2003), can delay the growth of the animal. Santos et al. (2004) also claim that forage quality greatly determines its effectiveness in animal performance. Thus, with better nutrition, these animals could better express their production potential and development, with a possible decrease in the age at the inflection point. Moreover, because it is a genetic group that was only subjected to natural selection (Mariante et al., 2009), the animals present performance traits that can be useful in breeding and conservation programs, to reduce age of body maturity.

In this study, the REA was measured, using an ultrasound equipment, to estimate muscle development. However, it was not possible to fit a statistical model to the results, possibly due to the random behavior between REA and age, and also due to the large variation in the size of the animals and their body condition, regardless of age. As the muscular deposition is related to the amount of protein present in the feed, and the conversion of this protein in muscle usually occurs in the early stages of the development curve, it is believed that the oscillation in the availability of native pastures may have caused this random behavior. However, according to Tarouco et al. (2005), ultrasound measurements can be used with a high degree 
of accuracy in estimating the individual merit of carcass and assist in selection and management decisions, based on traits related to body composition, which could not be demonstrated in this work. Silva et al. (2003) also stated that the use of ultrasound measurements, combined with live weight, can estimate, with high accuracy, hot carcass weight and with moderate accuracy, carcass yield.

High positive correlations between morphometric measurements were observed in this study (Table 1), but REA measurements presented low correlations with these morphometric measurements, possibly because this measurement is related to the amount of muscle present in the carcass, and these animals went through times of food shortage. It is known that the muscle deposition occurs during the rapid growth phase, and if this deposition was insufficient, it does not occur in the subsequent phases, even if the animals receive an excellent nutritional support later.

Mazza et al. (1994) found an average weight of $89 \mathrm{~kg}$ for Pantaneiro cattle at 6 months of age, $112 \mathrm{~kg}$ at 12 months of age, and $298 \mathrm{~kg}$ for adult animals, while Abreu et al. (2002) reported an average weight of $112 \mathrm{~kg}$ at weaning (6-8 months) for the same breed. These values are lower than those found for the majority of animals of the same age groups in this study (Figure 1). The increase in weights of the animals found in this study, compared with those previous studies, suggests a selection effect on the studied traits.

Alberti et al. (2008) reported height at withers between 103 and $113 \mathrm{~cm}$ for Jersey, Casina and Highlander breeds at 12 months of age, similarly to the Pantaneiro cattle around 13 months of age, but lower than the measurements found for Holstein $(133 \mathrm{~cm})$ and for Simmental, Danish Red, Marchigiana and Avileña breeds, which ranged from 123 to $126 \mathrm{~cm}$. Pantaneiro females showed an average rump width of approximately $28 \mathrm{~cm}$ at around 13 months of age, which differs from the widths found by Alberti et al. (2008), who studied fifteen cattle breeds, reporting rump widths ranging from 38 to $53 \mathrm{~cm}$. For body length, the values found for the Pantaneiro females at 13 months of age were similar to the results reported by those same authors for Highlander cattle, of $122 \mathrm{~cm}$, but different from the values found for Austuriana de los Valles, Pyrenean and Avileña breeds, whose body lengths ranged from 149 to $152 \mathrm{~cm}$.

Adult Pantaneiro cows showed lower average height at withers, body length and thoracic perimeter than the ones found by Bianchini et al. (2006), working with both females and males of several locally adapted Brazilian breeds such as Curraleiro Pé-Duro, Junqueira, Pantaneira, Crioula Lageana and Mocho Nacional, as well as two commercial breeds: Nellore and Holstein. The same authors found that breed influenced body measurements such as body length, height at withers, and thoracic perimeter, and that sex influenced body length, which may explain the differences found between the two studies. It may also be related to the experiment location, since the Pantaneiro cows of this study were evaluated in the Pantanal of Mato Grosso do Sul, the ecosystem where this genetic group was formed, while Biachini et al. (2006) evaluated the animals in the Cerrado of the Federal District.

According to Owens et al. (1993), deposition of total protein, or the transformation of protein into muscle tissue may be limited by nutrient intake, which may explain the low size of REA found for the Pantaneiro cattle at different ages (Figure 1). It is important to emphasize that these animals are raised on native pastures that probably do not contain the necessary nutrients that would allow them to demonstrate all their productive potential.

Working with animals from the same herd and raised exclusively on native pastures, Silva et al. (2004) reported that year and season of birth are important nongenetic factors that may influence the growth rate of Nellore cattle. The small size of Pantaneiro animals may be associated with the fact that these animals were born and raised in a peculiar environment, considering that the Pantanal of Mato Grosso do Sul faces severe drought and flood periods. It is known that among the various factors affecting postweaning growth, year and season of birth are especially important, due to the climatic conditions that may differ from year to year, leading to different nutritional conditions (Biffani et al., 1999).

Gil et al. (2001) reported that different breeds require different production systems, and that the combination of breeds and production systems results in different products by different attributes, such as the color of meat and fat, which leads us to regard the Pantaneiro as a sustainable option for extensive systems with native pastures of the Pantanal, and also as a possibility for crossbreeding programs for beef production in that region.

\section{Conclusions}

Pantaneiro cows show a slow growth curve and a low adult body weight, possibly due to the production system they are subjected to, with the unique climatic conditions and the nutritional restrictions found in the Pantanal region. In Pantaneiro cows reared in extensive systems only on natural pastures, the use of ultrasound is not effective to estimate the curve of muscular development, perhaps because this breed was not selected for weight gain. 


\section{Acknowledgments}

The authors thank the Conselho Nacional de Desenvolvimento Científico e Tecnológico (CNPq) for the financial support and fellowship granted to the first author.

\section{References}

ABREU, U.G.P.; McMANUS C.; MORENO-BERNAL, F.E. et al. Genetic and environmental factors influencing birth and 205 day weights of pantaneiro calves. Archivos de Zootecnia, v.51, p.83-89, 2002.

ALBERTI, P.; PANEA, B.; SAÑUDO, C. et al. Live weight, body size and carcass characteristics of young bulls of fifteen European breeds. Livestock Science, v.114, p.19-30, 2008.

BIANCHINI, E.; McMANUS, C.; LUCCI, C.M. et al. Características corporais associadas com a adaptação ao calor em bovinos naturalizados brasileiros. Pesquisa Agropecuária Brasileira, v.41, p.1443-1448, 2006.

BIFFANI, S.; MARTINS FILHO, R.; GIORGETTI, A. et al. Fatores ambientais e genéticos sobre o crescimento ao ano e ao sobreano de bovinos Nelore, criados no Nordeste do Brasil. Revista Brasileira de Zootecnia, v.28, p.468-473, 1999.

GIL, M.; SERRA, X.; GISPERT, M. et al. The effect of breedproduction systems on the myosin heavy chain 1, the biochemical characteristics and the colour variables of Longissimus thoracis from seven Spanish beef cattle breeds. Meat Science, v.58, p.181-188, 2001.

JULIANO, R.S.; RAMOS, A.F.; SANTOS, S.A. et al. Analysis of reproductive characteristics indicators of puberty in young Pantaneiro bulls. Archivos de Zootecnia, v.60, p.1-4, 2011.

KOURY FILHO, W. Escores visuais e suas relações com características de crescimento em bovinos de corte. 2005. 80f. Tese (Doutorado em Zootecnia) - Universidade Estadual Paulista, Jaboticabal.

MACITELLI, F.; BERCHIELLI, T.T.; SILVEIRA, R.N. et al. Biometria da carcaça e peso de vísceras e de órgãos internos de bovinos mestiços alimentados com diferentes volumosos e fontes protéicas. Revista Brasileira de Zootecnia, v.34, p.1751-1762, 2005.
MARIANTE, A.S.; ALBUQUERQUE, M.S.M.; EGITO, A.A. et al. Present status of the conservation of livestock genetic resources in Brazil. Livestock Science, v.120, p.204-212, 2009.

MAZZA, M.C.M.; MAZZA, C.A.S.; SERENO, J.R.B. et al. Etnobiologia e conservação do bovino Pantaneiro. Corumbá: Embrapa-CPAP, 1994. 61p.

MCCULLAGH, P.; NELDER, J.A. Generalized linear models. 2.ed. New York: Chapman \& Hall, 1989.

OWENS, F.N.; DUBESKI, P.; HANSON, C.F. Factors that alter the growth and development of ruminants. Journal Animal Science, v.71, p.3138-3150, 1993.

PEDROSO, E.K.; LOCATELI, A.L.; GROSSKLAUS, C. Avaliação funcional e carcaça do Nelore. In: SIMPÓSIO DE PRODUÇÃO DE GADO DE CORTE, 4., 2004, Viçosa, MG. Anais... Viçosa, MG, 2004. Available at: <http://simcorte.com/index/Palestras/q simcorte/simcorte4.PDF> Accessed on: July 15, 2012.

PRADO, I.N.; MOREIRA, F.R.; CECATO, U. et al. Sistemas para crescimento e terminação de bovinos de corte a pasto: Avaliação do desempenho animal e características da forragem. Revista Brasileira de Zootecnia, v.32, p.955-965, 2003.

ROBBINS, K.L.; NORTON, H.W.; BAKER D.H. Estimation of nutrient requeriments from growth data. Journal of Nutrition, v.109, p.1710-1714, 1979.

SANTOS, E.D.G.; PAULINO, M.F.; QUEIROZ, D.S. et al. Avaliação de pastagem diferida de Brachiaria decumbens Stapf. 2. Disponibilidade de forragem e desempenho animal durante a seca. Revista Brasileira de Zootecnia, v.33, p.214-224, 2004.

SANTOS, S.A.; ABREU, U.G.P.; SOUSA, G.S. et al. Condição corporal, variação de peso e desempenho reprodutivo de vacas de cria em pastagem nativa no Pantanal. Revista Brasileira de Zootecnia, v.38, p.354-360, 2009.

SILVA, S.L.; LEME, P.R.; PUTRINO, S.M. et al. Estimativa do peso e do rendimento de carcaça de tourinhos Brangus e Nelore, por medidas de ultra-sonografia. Revista Brasileira de Zootecnia, v.32, p.1227-1235, 2003.

SILVA, N.A.M.; AQUINO, L.H.; SILVA, F.F. et al. Curvas de crescimento e influência de fatores não-genéticos sobre as taxas de crescimento de bovinos da raça Nelore. Ciência e Agrotecnologia, v.28, p.647-654, 2004.

TAROUCO, J.U.; LOBATO, J.F.P.; TAROUCO, A.K. et al. Relação entre medidas ultra-sônicas e espessura de gordura subcutânea ou área de olho de lombo na carcaça em bovinos de corte. Revista Brasileira de Zootecnia, v.34, p.2074-2084, 2005. 